\title{
Relationship Between Risk Management Practices and Investment Decisions in Bank of Kigali, Rwanda
}

\section{| Gedion Alang'o Omwono ${ }^{1^{*}}$ | Kayumba Annette ${ }^{2}$ |}

\author{
${ }^{1}$ Senior lecturer school of \\ postgraduate, department of \\ Business Management and \\ Economics, university of \\ Kigali, Kigali city Rwanda \\ ${ }^{2} M B A$ (Finance \& Accounting) \\ student department of \\ Business Management \& \\ Economics, University of \\ Kigali, Kigali city Rwanda \\ "gedion.impact@gmail.com
}

\begin{abstract}
The purpose of this study was to examine the relationship between risk management practices and investment decisions in Bank of Kigali, Rwanda. This study adopted correlational research design. Descriptive statistics include those of the mean, standard deviation and frequency distribution while inferential statistics involves use of spearman's coefficient correlations. Linear regression was used where ANOVA was carried on each variable. The study found that there was a correlation between liquidity risk management, default risk management and market risk management with performance of the Banks. The study findings indicated that credit risk management $(r=0.096, p<0.01)$, liquidity risk management $(r=0.347, p<0.01)$, market risk management $(r=0.506, p<0.01)$ and operational risk management $(r=0.612, p<0.01)$ on financial performance. It however found that the Banks do not involve experts and consultants in market risk management thus recommendations were made for the Banks to revise their credit risk management policies, open up and share information with other players on market risk thus involve consultants more in their market risk management and to be more proactive than reactive in risk management. The study concluded that, risk management has a positive influence on the investment decisions and that risk monitoring can be used to make sure that risk management practices are in line with proper best practice risk monitoring policies which also helps bank management to discover exposures at early stages and make corrective actions. The study recommended that, Senior management should develop strategies, policies and practices to manage risk in accordance with the Banks risk tolerance and to ensure that the bank maintains sufficient liquidity risk cover.

KEYWORDS

Risk Management Practices and Investment decision in bank of Kigali; Rwanda.
\end{abstract}

\section{INTRODUCTION}

\section{Background to the study}

A recent study done by S. Egide \& K. Paul, (2017) noted that, Rwandan financial system is comprised of insurance, banking pension funds. The financial sector has fourteen (14) commercial banks; one development bank; two specialized banks; three micro-finance banks; one discount house, an estimated one hundred seventeen (117) micro-finance institutions currently operating and 416 Umurenge Sacco's, eleven (11) insurance companies and the Social Security Fund of Rwanda (National Bank of Rwanda[NBR], 2012 ). The Bank of Kigali include, Bank of Kigali, I \&M Bank Cogebanque, Access Bank, Ecobank, Guaranty Trust Bank, Kenya commercial Bank, Banque Populaire du Rwanda and Equity Bank. 


\section{Statement of the problem}

In an ideal situation, effective risk management is fundamental to the success of the Bank. Risk management is a strategic priority that is a responsibility shared by all of the Bank's employees. Banks has a strong, disciplined risk management culture. A key aspect of this culture is to be well-diversified across business lines, products, and industries. The primary goals of risk management are to ensure that the outcomes of risk-taking activities are predictable and consistent with the Bank's strategies and risk appetite, and that there is an appropriate balance between risk and reward in order to maximize shareholder returns.

Unfortunately, Bank of Kigali faces a challenge of low domestic savings estimated at $5 \%$ of GDP which is lower than $10 \%$ when compared to the benchmark of countries like Vietnam and Malaysia. This is because of low income which translates into low saving culture, low levels of financial literacy, limited and unattractive savings products. One of the key challenges facing Rwanda's economy is the mobilization of long-term stable financing. Rwanda's capital market is small and underdeveloped to enable public and private sector accessing long term financing. In terms of Market depth/breadth, the Rwanda capital market offers limited securities and products compared to other EAC countries, equity investments dominate other asset classes such as sovereign and municipal bonds, corporate bonds, and other convertible investments.

Various studies have been done in this area, in a study by Muteti, R.S (2013) on relationship between financial risk management and investment decisions of Bank of Kigali in Kenya, found that there was a negative relationship between credit risk, interest rate risk, foreign exchange risk, liquidity risk and investment decisions of Bank of Kigali in Kenya. In another study by Faris, N.A (2011) the effect of working capital practices on risk management: evidence from Jordan Firms have negative returns if they follow an aggressive working capital policy. However in a study by Taiwo ,J.N et al (2017) on Credit Risk Management: Implications on Bank Performance and Lending Growth, Ota Nigeria found that, credit risk management has an insignificant impact on the growth of total loans and advances by Nigerian Deposit money banks. Most studies on Risk management and investment decisions deviate from an in-depth analysis of the relationship between Risk management practices and investment decisions. This study therefore, examine the relationship between Risk management practices and investment decisions in Bank of Kigali, Rwanda

\section{Research Objectives}

This study was guided by the following research objectives:

i. To assess the effects of credit risk management and the investment decisions of Bank of Kigali in Rwanda.

ii. To determine the effects of liquidity risk management on the investment decisions of Bank of Kigali in Rwanda.

iii. To analyze the effects of market risk management on the investment decisions of Bank of Kigali in Rwanda.

iv. To establish the effects of operational risks management on the investment decisions of Bank of Kigali in Rwanda.

\section{Research hypotheses}

The study was guided by the following hypothesis

i. There is a relationship between credit risk management and investment decisions of Bank of Kigali in Rwanda. 
ii. There is a relationship between liquidity risk management and investment decisions of Bank of Kigali in Rwanda.

iii. There is a relationship between market risk management and the investment decisions of Bank of Kigali in Rwanda.

iv. There is a relationship between operational risk management and investment decisions of Bank of Kigali in Rwanda.

\section{METHOD}

\section{Research Design}

This study adopted a correlational research design in obtaining relationship between Risk management practices and investment decisions in the Bank of Kigali, Rwanda

\section{Study Population}

The target population under this study comprised of eleven branches of Bank of Kigali licensed by National Bank of Rwanda (BNR). Which were sampled as follows using simple random sampling

Table 2.1 Sample size

\begin{tabular}{lcc}
\hline Area of Operation & Population & Sample \\
\hline Branch managers & 11 & 8 \\
Assistant branch managers & 11 & 8 \\
Credit managers & 11 & 7 \\
Operations managers & 11 & 7 \\
Total & $\mathbf{4 4}$ & $\mathbf{3 0}$ \\
\hline
\end{tabular}

Source: Researcher 2018

\subsection{Data Collection Methods and Tools}

Both primary and secondary data tools were used under this study.

\section{RESULTS}

\section{Response Rate}

This study targeted 11 branches of Bank of Kigali in Rwanda. Out of 40 the questionnaires that were administered, 33 filled questionnaires were collected translating to $82.5 \%$ response rate which is satisfactory according to Babbie (2012) who argues that any response of 50\% and above is adequate for analysis. The response rate largely demonstrates a willingness of the respondents to participate in the study.

\section{Demographic Information}

Demographic information of the respondents was based on gender, age bracket, and duration in the Bank and the department where they work.

\section{Gender of the Respondents}

The study sought to determine the gender of the respondent and therefore requested the respondents to indicate their gender.

From the study, majority of the respondents were male staff, shown by $54 \%$, while $46 \%$ of them comprised of female staff. The findings show that Bank of Kigali have both male and female members; however, the majority of them are males. This implies that the views expressed in these findings are gender sensitive and can be taken as representative of the opinions of both genders as regards to the study topic. 


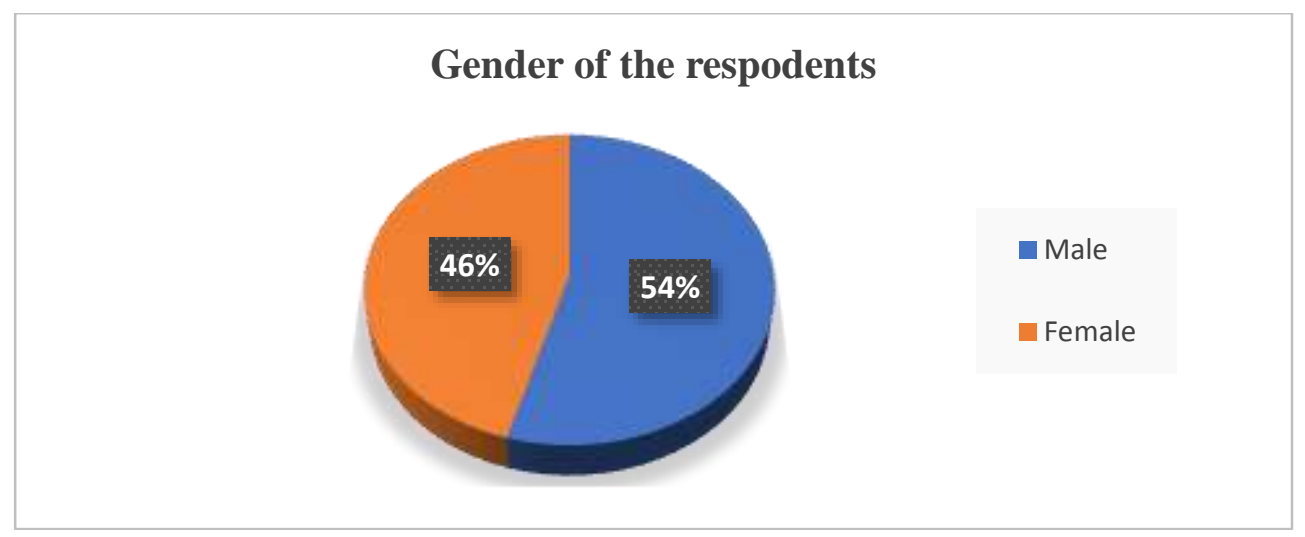

Figure 3.1 Classification of respondents by gender

\section{Age of the respondents}

The study sought to determine the distribution of age among the study respondents. The study investigated the composition of the respondent in terms of age. As shown in Table 3.1, majority (43\%) of the respondents were aged between 36 and 44 years, $21 \%$ of the respondents were aged between 26 and 35 years, $18 \%$ of the respondents were aged below 25 years. In addition, $12 \%$ were aged between 45 and 54 years while only $6 \%$ indicated that they were aged over 55 years above.

Table 3.1 Age of respondents

\begin{tabular}{llcc}
\hline Years & & Frequency & Percentage \\
\hline \multirow{4}{*}{ Valid } & $<25$ & 6 & 18 \\
& $26-35$ & 7 & 21 \\
& $36-44$ & 14 & 43 \\
& $45-54$ & 4 & 12 \\
& 55 years and above & 2 & 6 \\
& Total & $\mathbf{3 3}$ & $\mathbf{1 0 0}$ \\
\hline
\end{tabular}

The study findings show that more than majority of them were well distributed in terms of age and that they are active in productivity and hence can contribute constructively in this study.

\section{Education level of respondents}

The study further sought to determine the distribution of education qualifications among the respondents. Bank of Kigali offer employment to staff with varying academic qualifications. This section sought attempted to establish the highest academic qualifications attained by the respondents. As shown in Table 3.2, most (70\%) of the respondents had acquired a Bachelor's or undergraduate degrees level of education, while $30 \%$ of them indicated that they had acquired post graduate level.

Table 3.2 Education level of respondents

\begin{tabular}{llcc}
\hline & & Frequency & Percentage \\
\hline \multirow{3}{*}{ Valid } & Undergraduate & 23 & 70 \\
& Postgraduate & 10 & 30 \\
& Total & 33 & 100.0 \\
\hline
\end{tabular}

These findings show that most of the respondents had at least an undergraduate degree and hence understood the information sought by this study. In addition, the findings imply that all the respondents were academically qualified and also familiar with their duties and could dispense them effectively in terms of professional work ability and performance. 


\section{Designation of the Respondents}

Section 3.2.4 sought to establish the various positions held by the respondents in their organizations. The respondents indicated to be working either in the Audit or Risk departments in their organizations. Table 3.34 .5 shows their management levels where study findings in table $3.3,34 \%$ of the respondents indicated that they were officers; $27 \%$ supervisors; $24 \%$ middle level managers and $15 \%$ as senior managers.

Table 3.3 Designation of the Respondents

\begin{tabular}{llcc}
\hline Desgination & & Frequency & Percentage \\
\hline \multirow{4}{*}{ Valid } & Senior Manager & 5 & 15 \\
& Middle Level Manager & 8 & 24 \\
& Supervisor & 9 & 27 \\
& Office & 11 & 34 \\
& Total & $\mathbf{3 3}$ & $\mathbf{1 0 0}$ \\
\hline
\end{tabular}

Therefore, the respondents for the study were drawn from all the levels within the organizational structure of the Bank of Kigali as representative of the views of the various departments involved in Risk management.

\section{Duration of working banking sector}

The study further sought to determine the duration which the respondents had worked in banking sector. The length of service and working in an organization determines the extent to which one is aware of the issues sought by the study. Table 3.4 shows a summary of the findings. The study findings on the length of time that the respondents had been working in their respective Bank of Kigali where $36 \%$ of the respondents unanimously indicated that they had worked with their Bank of Kigali for a period of $10-15$ years; $24 \%$ for more than 15 years and $15 \%$ for $1-5$ years.

Table 3.4 Duration of working banking sector

\begin{tabular}{lcc}
\hline & Frequency & Percentage \\
\hline$<5$ & 5 & 15 \\
$5-10$ & 8 & 24 \\
$10-15$ & 12 & 36 \\
$>15$ & 8 & 24 \\
Total & $\mathbf{3 3}$ & $\mathbf{1 0 0}$ \\
\hline
\end{tabular}

\section{Discussion of results}

It is assumed that the longer one worked in an organization, the more they understand the organization and hence the higher the ability to articulate issues pertaining to the organization (Afande, 2013). During this study, length of working experience was tabulated and respondents were asked to tick the relevant option provided. Majority of the respondents have worked in their respective organization for a period of -15 years.

\section{Credit risk management on the Investment decisions}

Credit risk management is perceived to affect Bank of Kigali investments decision. Respondents' opinions against the statements were recorded using the scale shown below: 1-Strongly disagree; 2 - Disagree; 3 - Indifferent; 4 - Agree; 5 -Strongly agree.

Majority of the respondents agreed; Credit risk management must play its role then to help banks be in compliance with Basel II Accord and other regulatory bodies as shown by mean of 1.66, Risk monitoring can be used to make sure that risk management practices are in line and proper risk monitoring also helps bank management to discover mistake at early stage. 
As shown by a mean of 1.70, Risk often comes in investing and in the allocation of capital which must be assessed so as to derive a sound investment decision as shown by mean of 1.78. Banks should plan certain estimates, conduct monitoring, and perform reviews of the performance of the bank, as shown by a mean of 1.84 , Banks must have substantial amount of capital on its reserve, but not too much that it misses the investment revenue, and not too little that it leads itself to financial instability and to the risk of regulatory non-compliance as shown by a mean 1.97 .

Table 3.5 Statements relating to effects of credit risk management on the investment decisions

\begin{tabular}{lcc}
\hline \multicolumn{1}{c}{ Statements } & Mean & $\begin{array}{c}\text { Std. } \\
\text { Dev }\end{array}$ \\
\hline $\begin{array}{l}\text { Banks should plan certain estimates, conduct monitoring, and perform } \\
\text { reviews of the performance of the bank. }\end{array}$ & 1.84 & 0.23 \\
$\begin{array}{l}\text { Bank must have substantial amount of capital on its reserve, but not too } \\
\text { much that it misses the investment revenue, and not too little that it leads } \\
\text { itself to financial instability and to the risk of regulatory non-compliance } \\
\begin{array}{l}\text { Risk often comes in investing and in the allocation of capital which must be } \\
\text { assessed so as to derive a sound investment decision. }\end{array}\end{array}$ & 1.97 & 0.19 \\
$\begin{array}{l}\text { Credit risk management must play its role then to help banks be in } \\
\text { compliance with Basel II Accord and other regulatory bodies }\end{array}$ & 0.24 \\
$\begin{array}{l}\text { Risk monitoring can be used to make sure that risk management practices } \\
\text { are in line and proper risk monitoring and also helps bank management to } \\
\text { discover mistake at early stage. }\end{array}$ & 1.70 & 0.24 \\
\hline
\end{tabular}

\section{Discussion of results}

The above findings concur with the findings by Santomero (1997) he asserted that Credit risk management must play its role then to help banks be in compliance with Basel II Accord and other regulatory bodies.

In determining the effects of credit risk management on the on-investment decisions of Bank of Kigali, the study first found it necessary to evaluate the performance of the bank's investment decisions variables under consideration that is the ROA as the dependent variable and the ratio of loans to deposits as independent variables influencing the financial performance. Returns on Assets (ROA) were generated from the EBITs and the corresponding book value of total assets of a Bank of Kigali in a given year.

The resulting values are presented in the table in Appendix VI. The arithmetic means of ROA for the years 2014 to 2016 were calculated to provide the values of ROA as presented in the table in Appendix VI. The independent variable which was the credit risk was calculated by dividing total amounts of loans to the amounts of deposits for a Bank in a given year.

Table 3.6 Descriptive statistics of the Mean and standard deviation

\begin{tabular}{lcccc}
\hline & Minimum & Maximum & Mean & Std. Deviation \\
\hline ROA & -.0367 & .0437 & .01952 & .0131 \\
Credit Risk & .0265 & .5345 & .1629 & .1279 \\
\hline
\end{tabular}

Correlation analysis of ROA and Credit Risk

Correlation analysis of ROA and Credit Risk was done. Table 3.9 indicate that credit risk is significantly correlated to ROA $(\mathrm{r}=0.096, \mathrm{p}<0.01)$. There was weak correlation between ROA and Credit Risk. 
Table 3.7 Correlation between Credit risk and ROA

\begin{tabular}{|c|c|c|c|}
\hline & & Credit risk & ROA \\
\hline \multirow{3}{*}{ Credit risk } & Pearson Correlation & 1 & \\
\hline & Sig. (2-tailed) & & \\
\hline & $\mathrm{N}$ & 33 & \\
\hline \multirow{3}{*}{ ROA } & Pearson Correlation & $.096^{* *}$ & 1 \\
\hline & Sig. (2-tailed) & .000 & \\
\hline & $\mathrm{N}$ & 33 & 33 \\
\hline
\end{tabular}

Table 3.7 provides the regression analysis results and the regression statistics concerning the relationship between ROA and Credit Risk. The constant term of the correlation was 0.0179148 which was significantly different from zero $t_{(11)}=5.456, p>0.05$, the coefficient of credit risk was 0.00982604 which was not significant $t_{(11)}=0.6170, p>$ 0.05 , the regression was not statically significant $F_{(1,12)}=1.7319, p>0.05$, The variation in ROA was poorly explained by the variation in Credit Risk as shown by $R^{2}=0.009200$

Table 3.8 Regression Model and Regression Statistics

\begin{tabular}{lllll}
\hline & Coefficient & Std. Error & t-ratio & p-value \\
\hline Constant & 0.0179148 & 0.00328330 & 5.456 & 0.000002 .56 \\
CREDIT RISK & 0.00982604 & 0.0159249 & 0.6170 & 0.5406 \\
F $(1,11)$ & 0.380720 & & & 0.540630 \\
R-squared & 0.009200 & & & \\
Adjusted R-squared & -0.014965 & & & \\
\hline
\end{tabular}

The model for the relationship between ROA and Credit Risk is, therefore explained by the following model.

$\mathrm{ROA}=0.0179148+0.00982604$ (CREDIT RISK)

The correlation between ROA and Credit Risk was a value of $r(13)=0.0960$ this indicates that the pattern of changes in ROA across Bank of Kigali did not replicate the pattern of changes in credit risk. Their movements were independent to a large extent. From the regression analysis, the constant term was 0.0179148 which was significantly different from zero indicating that a part of variation in ROA could not be explained by variation in credit risk across commercial banks. The coefficient of Credit Risk was a positive value of 0.00982604 though not significantly different from zero. This indicates that Credit Risk did not strongly explain variation in ROA for Bank of Kigali in Rwanda. However, the coefficient of Credit risk was a positive value of 0.00982604 indicating that higher credit risk led to better investment decisions for Bank of Kigali as measured by an improvement in the ROA.

Also, further test on the beta coefficients of the resulting model, credit risk has a positive and significant relationship with banks performance $\left(\mathrm{R}^{2}=0.009200, \mathrm{p}=.000\right)$. It shows that $0.9 \%$ of the variation in banks performance is explained by Community-based activities. Further the credit risk has a positive and significant relationship with banks performance ( $\mathrm{p}$ $<.005)$ therefore, $\mathrm{H}_{1}$ is accepted.

\section{Discussion of results}

These findings are similar to those of the study done by Boahene, Dasah \& Agyei (2012). This study found that in Ghana, banks enjoyed high profitability in spite of high credit risk, contrary to the normal view that credit risk indicators were negatively related to profitability. Their results were attributed to prohibitive lending rates, fees and commission charged. 
The findings are in support of those by Afriyie \& Akotey (2011). In their study Afriyie \& Akotey (2011) sought to find out the effect of impact of credit risk management on the profitability of rural and community banks in the Brong Ahafo Region of Ghana. The study found a positive relationship between credit risk and profitability of the community banks. Just like the findings of this research, Afriyie \& Akotey (2011) found that the banks benefited from the high credit risk.

\section{Liquidity risk management on the Investment decisions}

Liquidity risk management is perceived to affect Bank of Kigali investments decisions. Respondents' opinions against the statements were recorded using the scale shown below: 1-Strongly disagree; 2 - Disagree; 3 - Indifferent; 4 - Agree; 5 -Strongly agree.

On respondent's level of agreement with the above statements relating to effects of liquidity risk management on the performance of commercial Bank form the findings, majority of the respondents agreed; holding more liquid assets and better matching cash-flows of assets and liabilities will reduce the liquidity risk of the Bank and protect it from insolvency but also reduce its profitability as shown by a mean of 1.73, Liquidity is crucial to the on-going viability of any bank, as illiquidity can have dramatic and rapid adverse effects on even well capitalized Banks as shown by mean a of 1.78 , Liquidity management should be a top priority for Bank management and regulators as shown by a mean of 1.92, the primary role of liquidity-risk management is to prospectively assess the need for funds to meet obligations and ensure the availability of cash or collateral to fulfill those needs at the appropriate time by coordinating the various sources of funds available to the institution under normal and stressed conditions as shown by mean a of 2.00 , the study also established that Liquidity risk management system is an important part of risk management system of commercial Banks, which should be commensurate with commercial Banks, property and complexity. Liquidity risk management policy should be in conformity with the general development strategy of the bank, and match the general financial strength of the bank, with the interaction and conversion of liquid risk and other risks fully taken into account.

Table 3.9 Statements relating to effects of Liquidity risk management on the investment decisions

\begin{tabular}{lcc}
\hline Statements & Mean & Std. Dev \\
\hline $\begin{array}{l}\text { Liquidity management should be a top priority for bank management and } \\
\text { regulators. }\end{array}$ & 0.92 \\
$\begin{array}{l}\text { The primary role of liquidity-risk management is to prospectively assess the need } \\
\text { for funds to meet obligations and ensure the availability of cash or collateral to }\end{array}$ & 0.18 \\
$\begin{array}{l}\text { fulfill those needs at the appropriate time by coordinating the various sources of } \\
\text { funds available to the institution under normal and stressed conditions }\end{array}$ & \\
$\begin{array}{l}\text { Liquidity is crucial to the on-going viability of any bank, as illiquidity can have } \\
\text { dramatic and rapid adverse effects on even well capitalized banks }\end{array}$ & 0.22 \\
$\begin{array}{l}\text { Holding more liquid assets and better matching cash-flows of assets and } \\
\text { liabilities will reduce the liquidity risk of the bank and protect it from insolvency } \\
\text { but also reduce its profitability. }\end{array}$ & 0.24 \\
\hline
\end{tabular}




\section{Discussion of results}

The above finding concurs with the study findings by (Sveriges Riksbank, 2011) he maintains that Liquidity management should be a top priority for Bank management and regulators.

\section{Correlation analysis of ROA and Liquidity risk}

Table 3.10 indicate that liquidity risk management on investment decisions $(r=0.347$, $\mathrm{p}<0.01$ ). This implies that liquidity risk management on investment decisions of Bank of Kigali in Rwanda.

Table 3.10 Correlation between liquidity risk management on financial performance

\section{Liquidity risk Investment decisions}

\begin{tabular}{|c|c|c|c|}
\hline \multirow{3}{*}{ Liquidity risk } & Pearson Correlation & 1 & \\
\hline & Sig. (2-tailed) & & \\
\hline & $\mathrm{N}$ & 33 & \\
\hline \multirow{3}{*}{ Investment decisions } & Pearson Correlation & $.347^{* * *}$ & 1 \\
\hline & Sig. (2-tailed) & .000 & \\
\hline & $\mathrm{N}$ & 33 & 33 \\
\hline
\end{tabular}

Furthermore, regression analysis was done to determine the effect of liquidity risk management on investment decisions and the following results were obtained. The results of the analysis are shown in Table 3.11.

Table 3.11 Model summary showing effect of liquidity risk management on investment decisions

\begin{tabular}{ccccc}
\hline Model & R & R Square & Adjusted R Square & Std. Error of the Estimate \\
\hline 1 & $.775^{\mathrm{a}}$ & .570 & .558 & .601
\end{tabular}

a. Predictors: (Constant), Liquidity risk management

Further analysis of the liquidity risk management on investment decisions obtained an adjusted $\mathrm{R} 55.8 \%$. This implies that the simple linear model with liquidity risk management as the independent variable explains $55.8 \%$ of the variations in investment decisions of commercial Banks. This means that when liquidity risk management was used investment decisions of the project changed by $55.8 \%$.

Table 3.12 ANOVA results showing the effect of Liquidity risk management on investment decisions

ANOVA $^{\mathrm{b}}$

\begin{tabular}{llccccc}
\hline Model & & Sum of Squares & Df & Mean Square & F & Sig. \\
\hline \multirow{3}{*}{1} & Regression & 18.177 & 1 & 18.177 & 50.334 & $.000^{\mathrm{a}}$ \\
& Residual & 13.723 & 70 & .3 .61 & & \\
& Total & 31.900 & 71 & & & \\
\hline
\end{tabular}

b. Dependent Variable: Investments decisions

c. Predictors: (Constant), Liquidity risk management

A regression analysis was done to determine the effect of liquidity risk management on investment decisions of Bank of Kigali in Rwanda. From the analysis, a p-value less than 0.05 (p-value $=0.0000)$ was obtained. This implies that the simple linear model with Liquidity risk management as the only independent variable is significant. Also, further test on the beta coefficients of the resulting model, liquidity risk management has a positive and significant relationship with banks performance $\left(\mathrm{R}^{2}=.570, \mathrm{~F}(1,71)=54.334, \mathrm{p}=.000\right)$. It 
shows that $55.8 \%$ of the variation in banks performance is explained by liquidity risk management. Further the liquidity risk management have a positive and significant relationship with banks performance $(\beta=0.755, \mathrm{t}=7.095, \mathrm{p}<.005)$ therefore, $\mathrm{H}_{2}$ is accepted.

Table 3.13 Coefficient results showing the relationship between liquidity risk management on investment decisions

Coefficients (a)

\begin{tabular}{llccccc}
\hline Model & & \multicolumn{2}{c}{ Unstandardized } & Standardized & T & Sig. \\
& & Coefficients & Coefficients & & \\
& & B & Std. & Beta & & \\
& & Error & & & \\
\hline 1 & (Constant) & .609 & .412 & & 1.478 & .000 \\
& Liquidity risk management & .806 & .114 & .755 & 7.095 & .000 \\
\hline
\end{tabular}

a. Dependent variable: Investment decisions

Correlation coefficients show that Liquidity risk management (X1) is significant ( $\mathrm{p}$-value $=0.0000)$ in influencing Investment decisions of Bank of Kigali (Y). The results of the analysis are shown in Table 3.13. The fitted model from this analysis is shown below:

ROE $=0.609+0.806$ (LIQUITITY RISK)

\section{Market Risk Management on the Investment decisions}

Market risk management is perceived to affect Bank of Kigali investments decisions. Respondents' opinions against the statements were recorded using the scale shown below: 1-Strongly disagree; 2 - Disagree; 3 - Indifferent; 4 - Agree; 5 -Strongly agree.

Table 3.14 Statements relating to effects of market risk management on the investment decisions

\begin{tabular}{|c|c|c|}
\hline Statements & Mean & Std. De \\
\hline $\begin{array}{l}\text { Market risk management helps to identify, measure, monitor, and control } \\
\text { exposure to market risk given the institution's size, complexity, and risk profile. }\end{array}$ & 1.84 & 0.23 \\
\hline $\begin{array}{l}\text { Market risk management helps to identify the sensitivity of the financial } \\
\text { Institution's earnings or the economic value of its capital to adverse changes in } \\
\text { interest rates, foreign exchanges rates, commodity prices, or equity prices. }\end{array}$ & 1.97 & 0.19 \\
\hline $\begin{array}{l}\text { As interest rates fluctuate the price of the asset will move in the opposite } \\
\text { direction resulting in a risk of not being able to sell bonds at the same price or } \\
\text { ending up with a lower than desirable interest rate on a loan }\end{array}$ & 1.78 & 0.24 \\
\hline $\begin{array}{l}\text { Banks with high exposure to one industry or one specific commodity are } \\
\text { exposed to commodity risk }\end{array}$ & 1.70 & 0.24 \\
\hline
\end{tabular}

On respondent's level of agreement with the above statements relating to effects of market risk management on the performance of commercial Bank form the findings, majority of the respondents agreed that; banks with high exposure to one industry or one specific commodity are exposed to commodity risk as shown by a mean of 1.65 , as interest rates fluctuate the price of the asset will move in the opposite direction resulting in a risk of not being able to sell bonds at the same price or ending up with a lower than desirable interest rate on a loan as shown by mean of 1.76, Market risk management helps to identify, measure, monitor, and control exposure to market risk given the institution's size, complexity, and risk profile as shown by mean of 1.84, Market risk management helps to identify the sensitivity of the 
financial institution's earnings or the economic value of its capital to adverse changes in interest rates, foreign exchanges rates,

Commodity prices or equity prices as shown by mean of 1.89 . The study further established that branches with market risk management may increases their reputation and opportunity to attract more wide customers in building their portfolio of fund resources; they may also increase their efficiency and profitability. The above findings concur with the study findings by Cebenoyan and Strahan (2004) they found that banks which have advanced in market risk management plan have greater credit availability, rather than reduced risk in the banking system. The greater credit availability leads to the opportunity to increase the productive assets and Bank's profit.

Table 3.15 Correlation between Market risks on investments decisions

\begin{tabular}{|c|c|c|c|}
\hline & & Market risk & Investments decisions \\
\hline & Pearson Correlation & 1 & \\
\hline Market risk & Sig. (2-tailed) & & \\
\hline & $\mathrm{N}$ & 33 & \\
\hline & Pearson Correlation & $.506^{* *}$ & 1 \\
\hline Investments decisions & Sig. (2-tailed) & .000 & \\
\hline & $\mathrm{N}$ & 33 & 33 \\
\hline
\end{tabular}

Table 3.15 indicate that market risk is significantly correlated to investment decisions $(\mathrm{r}=0.506, \mathrm{p}<0.01)$. This implies that market risk would result to investment decisions of Bank of Kigali in Rwanda.

Regression analysis was done to determine the effect of market risk on investment decisions in Rwanda. This analysis of the market risk obtained an adjusted $\mathrm{R} 46.8 \%$. This implies that the simple linear model with market risk as the independent variable explains $46.8 \%$ of the variations in investment decisions in Rwanda. This means that when market risk was used the investment decisions in Rwanda changed by $46.8 \%$. These results are presented in Table 3.16.

Table 3.16 Model summary showing market risk on investment decisions in Rwanda

\begin{tabular}{ccccc}
\hline Model & $\mathbf{R}$ & R Square & Adjusted R Square & Std. Error of the Estimate \\
\hline 1 & $.694^{\mathrm{a}}$ & .482 & .468 & .660 \\
\hline a. & Predictors: (Constant), Market risk & & \\
\hline
\end{tabular}

Table 3.17 ANOVA results showing the effect of market risk on investment decisions in Rwanda

ANOVA $^{\mathrm{b}}$

\begin{tabular}{lllllll}
\hline Model & & $\begin{array}{l}\text { Sum of } \\
\text { Squares }\end{array}$ & Df & Mean Square & F & Sig. \\
\hline \multirow{2}{*}{1} & Regression & 15.364 & 1 & 15.364 & 35.305 & $.000^{\mathrm{a}}$ \\
& Residual & 16.536 & 72 & .435 & & \\
& Total & 31.900 & 73 & & & \\
\hline
\end{tabular}

b. Dependent Variable: Investment decisions

c. Predictors: (Constant), Market risk

A regression analysis was done to determine the effect of market risk on investment decisions of Bank of Kigali. From the analysis, a p-value less than 0.05 ( $p$-value $=0.0000$ ) was obtained. This implies that the simple linear model with market risk as the only independent variable is significant. 
Also, further test on the beta coefficients of the resulting model, liquidity risk management has a positive and significant relationship with banks performance $\left(\mathrm{R}^{2}=.482\right.$, $\mathrm{F}(1,72)=35.305, \mathrm{p}=.000)$. It shows that $46.8 \%$. of the variation in banks performance is explained by market risk management. Further the liquidity risk management have a positive and significant relationship with Banks performance $(\beta=0.694, t=5.942, p<.005)$ therefore, $\mathrm{H}_{3}$ is accepted.

Table 3.18 Coefficient results showing the relationship between market risk on investment decisions

Coefficients (a)

\begin{tabular}{|c|c|c|c|c|c|c|}
\hline \multirow{2}{*}{\multicolumn{2}{|c|}{ Model }} & \multicolumn{2}{|c|}{$\begin{array}{l}\text { Unstandardized } \\
\text { Coefficients }\end{array}$} & \multirow{2}{*}{$\begin{array}{l}\text { Standardized } \\
\text { Coefficients } \\
\text { Beta }\end{array}$} & \multirow[t]{2}{*}{$\mathbf{T}$} & \multirow[t]{2}{*}{ Sig. } \\
\hline & & B & $\begin{array}{l}\text { Std. } \\
\text { Error }\end{array}$ & & & \\
\hline \multirow[t]{2}{*}{1} & (Constant) & 1.382 & .363 & & 3.803 & .000 \\
\hline & Market risk & .591 & .099 & .694 & 5.942 & .000 \\
\hline
\end{tabular}

Dependent variable: Investment decisions

Correlation coefficients show that Market risk $(X 3)$ is significant (p-value $=0.0000$ ) in influencing investment decisions of Bank of Kigali in Rwanda (Y). The results of the analysis are shown in Table 3.18. The fitted model from this analysis is shown below:

$\mathrm{ROE}=1.382+0.591$ (MARKET RISK)

\section{Operational Risk Management on the Investment decisions}

Operational risk management is perceived to affect Bank of Kigali investments decisions. Respondents' opinions against the statements were recorded using the scale shown below: 1-Strongly disagree; 2 - Disagree; 3 - Indifferent; 4 - Agree; 5 -Strongly agree.

Table 3.19 Statements relating to effects of operational risk management on the investment decisions

\begin{tabular}{|c|c|c|}
\hline Statements & Mean & Std. De \\
\hline $\begin{array}{l}\text { Aost financial risks are handled centrally, but operational risks are usually } \\
\text { nplemented in the various operational units relating to the risk. }\end{array}$ & 1. & 0.23 \\
\hline $\begin{array}{l}\text { Basel committee encourages banks to establish more sophisticated operational } \\
\text { risk measurement systems and practices such as the Advanced Measurement } \\
\text { Approach }\end{array}$ & 1.57 & 0.28 \\
\hline $\begin{array}{l}\text { Banks often calculate the operational risk coverage by estimating the } \\
\text { probability of an occurrence of a particular event and the potential loss from this } \\
\text { event }\end{array}$ & 1.76 & 0.24 \\
\hline $\begin{array}{l}\text { About half of all operational risk events that occurs in banks are problems within } \\
\text { the institution's control and that a small amount was caused by process failures } \\
\text { regarding monitoring and reporting }\end{array}$ & 1.76 & 0.24 \\
\hline $\begin{array}{l}\text { Operational risks hold no strategic value for the firm since they in the long run } \\
\text { will diminish the value of the company }\end{array}$ & 1.62 & 0.26 \\
\hline
\end{tabular}

On respondent's level of agreement with the above statements relating to effects of Operational risk management on the investments decisions of commercial bank form the findings, majority of the respondents agreed that; Basel committee encourages banks to establish more sophisticated operational risk measurement systems and practices such as the Advanced Measurement Approach as shown by mean of 1.57, operational risks hold no strategic value for the firm since they in the long run will diminish the value of the company 
as shown by a mean of 1.62 , most financial risks are handled centrally, but operational risks are usually implemented in the various operational units relating to the risk as shown by a mean of 1.68, about half of all operational risk events that occurs in banks are problems within the institution's control and that a small amount was caused by process failures regarding monitoring and reporting, banks often calculate the operational risk coverage by estimating the probability of an occurrence of a particular event and the potential loss from this event as shown by a mean of 1.76 in each case. The study further established that it is of crucial importance that Banks practice operational risk management so as to safe guard the assets of the banks and protect the investors' interests. The above findings concur with the study findings by Dunnet et al. (2005) they argue that banks often calculate the operational risk coverage by estimating the probability of an occurrence of a particular event and the potential loss from this event.

Table 3.20 Correlation between operational risks on investments decisions

\begin{tabular}{|c|c|c|c|}
\hline & & Operational risk & Investments decisions \\
\hline \multirow{4}{*}{ Operational risk } & Pearson Correlation & 1 & \\
\hline & Sig. (2-tailed) & & \\
\hline & $\mathrm{N}$ & 33 & \\
\hline & Pearson Correlation & $.612^{* *}$ & 1 \\
\hline Investments decisions & Sig. (2-tailed) & .000 & \\
\hline **. Correlation is sign & $\begin{array}{l}\mathrm{N} \\
\text { ificant at the } 0.01 \text { lev }\end{array}$ & iled). & 33 \\
\hline
\end{tabular}

Table 3.20 indicate that operational risk is significantly correlated to investment decisions $(\mathrm{r}=0.612, \mathrm{p}<0.01)$. This implies that operational risk would result to investment decisions of Bank of Kigali.

\section{Test of Hypothesis.}

The initial effort to examine the relationships proposed by the research model involved conducting multiple regression analysis. Multiple regression analysis is used to analyze the relationship between a single dependent variable and several predictor variables (Hair et al. 2006). The researcher used linear regression analysis to test the first three null hypotheses. Linear regression is an approach to modelling the relationship between a scale of variable $Y$ or more variables denoted as $\mathrm{X}$. To test hypothesis four, the researcher used multiple regression analysis to estimate the interaction effect and test the effect of risk management on investment decisions of Bank of Kigali in Rwanda.

The F-test was used further to determine the validity of the model while R squared was used as a measure of the model goodness of fit. The regression coefficient summary was then used to explain the nature of the relationship between the dependent and independent variables.

\section{Hypothesis one: There is a relationship between credit risk management and inverst- ment decisions of Bank of Kigali in Rwanda.}

The correlation between ROA and Credit Risk was a value of $r(13)=0.0960$ this indicates that the pattern of changes in ROA across Bank of Kigali did not replicate the pattern of changes in credit risk. Their movements were independent to a large extent. From the regression analysis, the constant term was 0.0179148 which was significantly different from zero indicating that a part of variation in ROA could not be explained by variation in credit risk across commercial Banks. The coefficient of Credit Risk was a positive value of 0.00982604 though not significantly different from zero. This indicates that Credit Risk did not strongly explain variation in ROA for Bank of Kigali in Rwanda. However, the 
coefficient of Credit risk was a positive value of 0.00982604 indicating that higher credit risk led to better investment decisions for Bank of Kigali as measured by an improvement in the ROA.

Table 3.21 Regression Model and Regression Statistics

\begin{tabular}{lllll}
\hline & Coefficient & Std. Error & t-ratio & p-value \\
\hline Constant & 0.0179148 & 0.00328330 & 5.456 & 0.000002 .56 \\
CREDIT RISK & 0.00982604 & 0.0159249 & 0.6170 & 0.5406 \\
F $(1,11)$ & 0.380720 & & & 0.540630 \\
R-squared & 0.009200 & & & \\
Adjusted R-squared & -0.014965 & & & \\
\hline \multicolumn{1}{c}{ The model for the relationship between ROA and Credit Risk is, therefore explained by }
\end{tabular}

The model for the relationship between ROA and Credit Risk is, therefore explained by the following model.

ROA $=0.0179148+0.00982604$ (CREDIT RISK)

Also, further test on the beta coefficients of the resulting model, credit risk has a positive and significant relationship with banks performance $\left(\mathrm{R}^{2}=0.009200, \mathrm{p}=.000\right)$. It shows that $0.9 \%$ of the variation in banks performance is explained by Community-based activities. Further the credit risk has a positive and significant relationship with banks performance ( $\mathrm{p}$ $<.005)$ therefore, $\mathrm{H}_{1}$ is accepted.

\section{Discussion of results}

These findings are similar to those of the study done by Boahene, Dasah \& Agyei (2012). This study found that in Ghana, Banks enjoyed high profitability in spite of high credit risk, contrary to the normal view that credit risk indicators were negatively related to profitability. Their results were attributed to prohibitive lending rates, fees and commission charged. The findings are in support of those by Afriyie \& Akotey (2011). In their study Afriyie \& Akotey (2011) sought to find out the effect of impact of credit risk management on the profitability of rural and community banks in the Brong Ahafo Region of Ghana. The study found a positive relationship between credit risk and profitability of the community banks. Just like the findings of this research, Afriyie \& Akotey (2011) found that the Banks benefited from the high credit risk.

Hypothesis two: There is a relationship between liquidity risk management and investment decisions of Bank of Kigali in Rwanda.

Furthermore, regression analysis was done to determine the effect of liquidity risk management on investment decisions and the following results were obtained. The results of the analysis are shown in Table 3.11.

Table 3.22 Model summary showing effect of liquidity risk management on investment decisions

\begin{tabular}{ccccc}
\hline Model & R & R Square & Adjusted R Square & Std. Error of the Estimate \\
\hline 1 & $.775^{\mathrm{a}}$ & .570 & .558 & .601 \\
\hline
\end{tabular}

b. Predictors: (Constant), Liquidity risk management

Further analysis of the liquidity risk management on investment decisions obtained an adjusted $\mathrm{R} 55.8 \%$. This implies that the simple linear model with liquidity risk management as the independent variable explains $55.8 \%$ of the variations in investment decisions of commercial Banks. This means that when liquidity risk management was used investment decisions of the project changed by $55.8 \%$.

Table 3.23 ANOVA results showing the effect of Liquidity risk management on investment decisions 


\begin{tabular}{lllllll}
\multicolumn{7}{c}{ ANOVA $^{\mathrm{b}}$} \\
\hline Model & & $\begin{array}{l}\text { Sum of } \\
\text { Squares }\end{array}$ & Df & Mean Square & F & Sig. \\
\hline \multirow{3}{*}{1} & Regression & 18.177 & 1 & 18.177 & 50.334 & $.000^{\mathrm{a}}$ \\
& Residual & 13.723 & 70 & .3 .61 & & \\
& Total & 31.900 & 71 & & & \\
\hline
\end{tabular}

b. Dependent Variable: Investment decisions

c. Predictors: (Constant), Liquidity risk management

A regression analysis was done to determine the effect of liquidity risk management on investment decisions of Bank of Kigali in Rwanda. From the analysis, a p-value less than 0.05 (p-value $=0.0000)$ was obtained. This implies that the simple linear model with Liquidity risk management as the only independent variable is significant. Also, further test on the beta coefficients of the resulting model, liquidity risk management has a positive and significant relationship with Banks performance $\left(\mathrm{R}^{2}=.570, \mathrm{~F}(1,71)=54.334, \mathrm{p}=.000\right)$. It shows that $55.8 \%$ of the variation in Banks performance is explained by liquidity risk management. Further the liquidity risk management have a positive and significant relationship with banks performance $(\beta=0.755, \mathrm{t}=7.095, \mathrm{p}<.005)$ therefore, $\mathrm{H}_{2}$ is accepted.

Table 3.24 Coefficient results showing the relationship between liquidity risk management on investment decisions

Coefficients (a)

\begin{tabular}{llccccc}
\hline Model & & \multicolumn{2}{c}{ Unstandardized } & Standardized & T & Sig. \\
& & Coefficients & Coefficients & & \\
& & B & Std. & Beta & & \\
& & Error & & & \\
\hline 1 & (Constant) & .609 & .412 & & 1.478 & .000 \\
& Liquidity risk management & .806 & .114 & .755 & 7.095 & .000 \\
\hline
\end{tabular}

b. Dependent variable: Investment decisions

Correlation coefficients show that Liquidity risk management $(\mathrm{X} 1)$ is significant ( $\mathrm{p}$-value $=0.0000)$ in influencing Investment decisions of Bank of Kigali(Y). The results of the analysis are shown in Table 3.13. The fitted model from this analysis is shown below:

ROE $=0.609+0.806$ (LIQUITITY RISK)

Hypothesis three: There is a relationship between market risk management and the investment decisions of Bank of Kigali in Rwanda.

Regression analysis was done to determine the effect of market risk on investment decisions in Rwanda. This analysis of the market risk obtained an adjusted R 46.8\%. This implies that the simple linear model with market risk as the independent variable explains $46.8 \%$ of the variations in investment decisions in Rwanda. This means that when market risk was used the investment decisions in Rwanda changed by $46.8 \%$. These results are presented in Table 3.16 .

Table 3.25 Model summary showing market risk on investment decisions in Rwanda

\begin{tabular}{ccccc}
\hline Model & $\mathbf{R}$ & R Square & Adjusted R Square & Std. Error of the Estimate \\
\hline 1 & $.694^{\mathrm{a}}$ & .482 & .468 & .660 \\
\hline b. & Predictors: (Constant), Market risk & & \\
\hline
\end{tabular}


Table 3.26 ANOVA results showing the effect of market risk on investment decisions in Rwanda

ANOVA $^{\mathrm{b}}$

\begin{tabular}{lllllll}
\hline & Model & $\begin{array}{l}\text { Sum of } \\
\text { Squares }\end{array}$ & Df & Mean Square & F & Sig. \\
\hline \multirow{2}{*}{1} & Regression & 15.364 & 1 & 15.364 & 35.305 & $.000^{\mathrm{a}}$ \\
& Residual & 16.536 & 72 & .435 & & \\
\hline & Total & 31.900 & 73 & & & \\
\hline
\end{tabular}

b. Dependent Variable: Investment decisions

c. Predictors: (Constant), Market risk

A regression analysis was done to determine the effect of market risk on investment decisions of Bank of Kigali. From the analysis, a p-value less than 0.05 (p-value $=0.0000$ ) was obtained. This implies that the simple linear model with market risk as the only independent variable is significant.

Also, further test on the beta coefficients of the resulting model, liquidity risk management has a positive and significant relationship with banks performance $\left(\mathrm{R}^{2}=.482\right.$, $\mathrm{F}(1,72)=35.305, \mathrm{p}=.000)$. It shows that $46.8 \%$. of the variation in banks performance is explained by market risk management. Further the liquidity risk management have a positive and significant relationship with banks performance $(\beta=0.694, t=5.942, p<.005)$ therefore, $\mathrm{H}_{3}$ is accepted.

Table 3.27 Coefficient results showing the relationship between market risk on investment decisions

Coefficients (a)

\begin{tabular}{llccccc}
\hline Model & & \multicolumn{2}{c}{ Unstandardized } & Standardized & T & Sig. \\
& & Coefficients & Coefficients & & \\
& & B & Std. & Beta & & \\
& & & Error & & & \\
\hline 1 & (Constant) & 1.382 & .363 & & 3.803 & .000 \\
& Market risk & .591 & .099 & .694 & 5.942 & .000 \\
\hline
\end{tabular}

a. Dependent variable: Investment decisions

Correlation coefficients show that Market risk $(X 3)$ is significant (p-value $=0.0000)$ in influencing investment decisions of Bank of Kigali in Rwanda (Y). The results of the analysis are shown in Table 3.19.. The fitted model from this analysis is shown below:

$\mathrm{ROE}=1.382+0.591$ (MARKET RISK)

Hypothesis four: There is a relationship between operational risk management and investment decisions of Bank of Kigali in Rwanda.

Regression analysis was done to determine the effect of operational risk on investment decisions of Bank of Kigali. This analysis of the operational risk obtained an adjusted $\mathrm{R}$ $47.0 \%$. This implies that the simple linear model with operational risk as the independent variable explains $47.0 \%$ of the variations in operational risk. This means that when operational risk was used the investment decisions of Bank of Kigali changed by $47.0 \%$. These results are presented in Table 3.28.

Table 3.28 Model summary showing effect of operational risk

\begin{tabular}{|c|c|c|c|c|}
\hline Model I & $\mathbf{R}$ & R Square & Adjusted R Square & Std. Error of the Estimate \\
\hline 1 & $.696^{\mathrm{a}}$ & .484 & .470 & .658 \\
\hline
\end{tabular}


Table 3.29 ANOVA results showing the effect of operational risk on investment decisions of Bank of Kigali in Rwanda.

ANOVA $^{b}$

\begin{tabular}{lllllll}
\hline Model & & Sum of Squares & Df & Mean Square & F & Sig. \\
\hline \multirow{3}{*}{1} & Regression & 15.432 & 1 & 15.432 & 35.607 & $.000^{\mathrm{a}}$ \\
& Residual & 16.468 & 69 & .433 & & \\
& Total & 31.900 & 70 & & & \\
\hline
\end{tabular}

b. Dependent Variable: Investment decisions

c. Predictors: (Constant), Operational risk

A regression analysis was done to determine the effect of operational risk on Investment decisions of Bank of Kigali. From the analysis, a p-value less than 0.05 (p-value $=0.0000$ ) was obtained. This implies that the simple linear model with operational risk as the only independent variable is significant.

Also, further test on the beta coefficients of the resulting model, liquidity risk management has a positive and significant relationship with banks performance $\left(\mathrm{R}^{2}=.484\right.$, $\mathrm{F}(1,72)=35.607, \mathrm{p}=.000)$. It shows that $47 \%$. of the variation in banks performance is explained by market risk management. Further the liquidity risk management have a positive and significant relationship with banks performance $(\beta=0.696, t=5.967, p<.005)$ therefore, $\mathrm{H}_{4}$ is accepted.

Table 3.30 Coefficient results showing the relationship between operational risk and investment decisions

$$
\text { Coefficients (a) }
$$

\begin{tabular}{llccccc}
\hline Model & & \multicolumn{2}{c}{ Unstandardized } & Standardized & T & Sig. \\
& & Coefficients & Coefficients & & \\
& & B & Std. & Beta & & \\
& & Error & & & \\
\hline 1 & (Constant) & 1.510 & .341 & & 4.423 & .000 \\
& Operational risks & .592 & .099 & .696 & 5.967 & .000 \\
\hline
\end{tabular}

a. Dependent variable: Investment decisions

Correlation coefficients show that operational risks $(X 4)$ is significant (p-value $=0.0000)$ in influencing Investment decisions of Bank of Kigali(Y). The results of the analysis are shown in Table 3.23.. The fitted model from this analysis is shown below:

$\mathrm{ROE}=1.510+0.592$ (OPERATIONAL RISKS).

\section{Regression Analysis}

Regression analysis was done to examine the effect of enterprise risk management practices on investment decisions of Bank of Kigali.

Table 3.31 Model Summary

\begin{tabular}{lllll}
\hline Model & $\mathrm{R}$ & R Square & Adjusted R Square & Std. Error of the Estimate \\
\hline 1 & $.542^{\mathrm{a}}$ & .294 & .268 & .130 \\
\hline
\end{tabular}

a. Predictors: (Constant), Credit risk, Liquidity risk, Market risks, and operational risks

Table 3.31 shows that the coefficient of determination $\mathrm{R}$ square is 0.294 and $\mathrm{R}$ is 0.542 at 0.05 significant level. The coefficient of determination indicates that $29.4 \%$ of the variation in the dependent variable Bank of Kigali investment decisions is explained by the independent variables (Credit risk, Liquidity risk, Market risks, and operational risks). 
Table 3.32 ANOVA $^{\mathrm{a}}$

\begin{tabular}{lllllll}
\hline Model & & Sum of Squares & df & Mean Square & F & Sig. \\
\hline \multirow{3}{*}{1} & Regression & $.575^{\mathrm{a}}$ & 3 & .192 & 11.388 & $.000^{\mathrm{b}}$ \\
& Residual & 1.379 & 82 & .017 & & \\
& Total & 1.953 & 85 & & & \\
\hline
\end{tabular}

a. Dependent Variable: Investment decisions

b. Predictors: (Constant), Credit risk, Liquidity risk, Market risks, and operational risks

Table 3.32. presents the results of Analysis of Variance (ANOVA) on enterprise risk management versus investment decisions of Bank of Kigali in Rwanda. The ANOVA results for regression coefficient indicate that the significance of the $F$ is 0.00 which is less than 0.05. This implies that there is a positive significant relationship between enterprise risk management versus investment decisions of Bank of Kigali and that the model is a good fit for the data.

Table 3.33 Coefficient results showing the relationship between the combined risk management and investment decisions

\begin{tabular}{|c|c|c|c|c|c|c|}
\hline \multirow{2}{*}{\multicolumn{2}{|c|}{ Model }} & \multicolumn{2}{|c|}{$\begin{array}{l}\text { Unstandardized } \\
\text { Coefficients }\end{array}$} & \multirow{2}{*}{$\begin{array}{c}\text { Standardized } \\
\text { Coefficients } \\
\text { Beta }\end{array}$} & \multirow[t]{2}{*}{$\mathbf{t}$} & \multirow[t]{2}{*}{ Sig. } \\
\hline & & $\mathbf{B}$ & $\begin{array}{l}\text { Std. } \\
\text { Error }\end{array}$ & & & \\
\hline \multirow[t]{5}{*}{1} & (Constant) & .455 & .231 & & 1.973 & .106 \\
\hline & Credit risk & .162 & .009 & .444 & 1.815 & .009 \\
\hline & Liquidity risk & .187 & .050 & 1.231 & 3.616 & .036 \\
\hline & Market risk & .158 & .017 & 1.075 & 3.159 & .025 \\
\hline & Operational risk & .205 & .240 & .230 & .850 & .028 \\
\hline
\end{tabular}

From the data in the above table the established regression equation was

$\mathrm{Y}=0.455+0.162 \mathrm{X} 1+0.187 \mathrm{X} 2+0.158 \mathrm{X} 3+0.205 \mathrm{X} 4$

From the above regression equation, it was revealed that holding Credit risk, Liquidity risk, Market risks, and operational risks to a constant zero, investment decisions would be at 0.455. A unit increase on credit risk management would lead to increase in investment decisions by a factor of 0.162 , a unit increase in Liquidity risk would lead to increase in investment decisions by a factor of 0.187 , a unit increase in market risk would lead to increase in investment decisions by a factor of 0.158 and unit increase in operational would lead to increase in investment decisions by a factor of 0.205 .

\section{DISCUSSION}

The first objective of the study was to determine the effects of credit risk management on the Bank of Kigali. From this research, it was found that credit risk management has a significant effect on the investment decisions of Bank of Kigali. From this study, it was found that there is a positive relationship between credit risk management and financial performance. From the obtained data, it was also found that there is evidence of a significant effect of gender, age and number of years worked on the perception of employees about the effect of credit risk management on the investment decisions Bank of Kigali in Rwanda. From the study, it was also found that there is evidence of significant effect of credit risk management on the quality of services offered by Bank of Kigali

The second objective was to determine the effects of liquidity risk management on the investment decisions of Bank of Kigali. From the study, it was found that there is a positive relationship between liquidity risk and investment decisions of commercial banks. It was also found that there is a positive effect of liquidity risk and investment decisions of 
Bank of Kigali in Rwanda. From the obtained data, it was also that there is evidence of a significant effect of gender, age and number of years worked on the perception of employees about the effect of liquidity risk management on performance of financial institutions in Rwanda.

The third objective of the study was to examine the effects of market risk management on the investment decisions of Bank of Kigali Rwanda. To ascertain the contribution of market risk practice to the investment decisions of Bank of Kigali Rwanda. From this research, it was found that there is a positive correlation between market risk management and investment decisions of Bank of Kigali in Rwanda. It was found that market risks management have a positive effect on financial institutions in Rwanda.

The fourth objective of the study was to determine the effects of operational risks management on the investment decisions of Bank of Kigali in Rwanda. From this research, it was found that there is a positive correlation between operational risks management and investment decisions of Bank of Kigali in Rwanda. Analysis of the operational risks management obtained an adjusted $\mathrm{R} 47.0 \%$. This implies that the simple linear model with operational risks management as the independent variable explains $47.0 \%$ of investment decisions of Bank of Kigali in Rwanda. This means that when operational risks were used investment decisions of Bank of Kigali in Rwanda changed by $47.0 \%$.

\section{RECOMMENDATIONS}

\section{Credit risk on financial performance}

Clear credit policies and lending guidelines should be established. Management also is required to make sure that the terms and conditions are adhered to in loans approval. Hence lending guidelines should be approved by senior management and made aware to all staffs. This will reduce loss on nonperforming loans and improve the asset quality management which raises banks' expenses and consequently increase profitability. It is also recommended that the bank need to monitor the loan and advances to total deposits ratio frequently since it also affects profitability.

Based on the findings, the study recommends that Supervisors should regularly perform a Comprehensive assessment of a Bank 's overall credit risk management framework and credit position to determine whether they deliver an adequate level of resilience to credit stress given the banks role in the financial system. Supervisors should supplement their regular assessments of a Bank's credit risk management framework and liquidity position by monitoring a combination of internal reports, prudential reports and market information.

\section{REFERENCES}

Apanga, M., Appiah, K., \& Arthur, J. (2016). 'Credit risk management of Ghanaian listed banks. International Journal of Law and Management', 58(2), 162 - 178.

Duaka, C. (2015). 'Credit Risk Management in Commercial Banks'. Journal of Economics and Finance, 6(3), 51-56.

Ernest Somuah Annor \& Fredrick Somuah Obeng (2018) 'impact of Credit Risk Management on Profitability of selected Bank of Kigali Listed in Ghana stock Exchange:' journal published by international Journal of Economics, Management and Trade 20(2): 1-10, 2017; Article no.JEMT.36881 ISSN: 2456-9216 (Past name: British Journal of Economics, Management \& Trade, and Past ISSN: 2278-098X)

Paul (2017) 'enterprise risk management practices and investment decisions of Bank of Kigaliin rwanda.' Jounal published by European Journal of Business and Social Sciences, Vol. 6, No. 06, September 2017. P.P. 112 - 127 URL: http://www.ejbss.com/recent.aspx-/ ISSN: 2235 -767X 
Faris, Nasir.Alshubir (2011), 'the effects of working capital on risks management': Evidence from Jordan. Published by Global journal Research, volume 1 number 5, 2011

Suleiman. Kargi(2011). 'Credit risk and the performance of Nigerian banks. Department of accounting Faculty of Administration',Ahmadu Bello University, Zaria - Nigeria: Science Vol. 3 No 7;

Kallet, Richard H. (2004)."How to Write the Methods Section of a Research Paper." Respiratory Care 49 1229-1232.

Muteti, Raymond .Sammy (2013) on 'relationship between financial risk management and investment decisions of Bank of Kigaliin Kenya', unpublished journal from university of Nairobi library, Nairobi Kenya

kagoyire, Alice \& shukla, Jaya (2016) 'effect of credit management on performance of commercial bank a case of Equity Bank Rwanda': journal published by European Centre for Research Training and Development UK (www.eajournals.org) vol. 4 No.4 PP1-12

Nawaz, M., Munir, S., Siddiqui, S. A., Tahseen-ul-Ahad, F. A., Asif, M., \& Ateeq, M. (2012). 'Credit risk and the performance of Nigerian banks'. Interdisciplinary Journal of Contemporary Research in Business, 4(7), 49- 63.

Osuka, B. \& Amako, J. (2015). "Credit Management in Nigeria Deposit Money Bank (20032013) (A Study of Selected Deposit Money Banks)". International Research Journal of Education and Innovation (IRJEI), Vol 1, No3, pp 66 - 103

Owojori, A.A., I.R. Akintoye \& F.A. Adidu, (2011). 'The challenge of risk management in Nigerian banks in the post consolidation era'. Journal of Accounting and Taxation, 3(2): 23- 31.

Sempambwe, egide \& Kariuki, Paul, (2017) 'Enterprise risk management practices and financial.' Journal published by European Journal of Business and Social Sciences, Vol. 6, No. 06, September 2017. P.P. 112 - 127 URL: http://www.ejbss.com/recent.aspx-/ ISSN: $2235-767 \mathrm{X}$

Tafri, F. H., Hamid, Z., Meera, A., \& Omar, M. A. (2010). 'The Impact of Financial Risks on Profitability of Malaysian Commercial Banks': 1996-2005. . Submitted to the Journal of Emerging Market Finance, 11.

Taiwo Joseph,N; Ucheaga, EG; Achugamonu, BU; Adetiloye, K. ; Okoye, L., \&Agwu, M.E (2017), 'Credit Risk Management: Implications on Bank Performance and Lending Growth', journal published by Saudi Journal of Business and Management Studies ISSN 2415 -6663 (Print) Scholars Middle East Publishers ISSN 2415-6671 (Online) Dubai, United Arab Emirates Website: http://scholarsmepub.com/ 